\title{
A Recessive Allele (tgr-1) Conditioning Tomato Resistance to Geminivirus Infection Is Associated with Impaired Viral Movement
}

\author{
Xue-Yu Bian, Mark R. Thomas, M. Saif Rasheed, Muhammad Saeed, \\ Peter Hanson, Paul J. De Barro, and M. Ali Rezaian
}

First, second, third, fourth, and seventh authors: CSIRO Plant Industry, PO Box 350, Glen Osmond, SA 5064, Australia; fifth author: Asian Vegetable Research and Development Centre, P.O. Box 42, Shanhua, Tainan 741, Taiwan; and sixth author: CSIRO Entomology, Long Pocket Laboratories, Indooroopilly, QLD 4068, Australia.

Current address of X.-Y. Bian: BioMarka, the School of Agriculture and Food Systems, The University of Melbourne, VIC 3010, Australia. Accepted for publication 6 February 2007.

\section{ABSTRACT}

Bian, X.-Y., Thomas, M. R., Rasheed, M. S., Saeed, M., Hanson, P., De Barro, P. J., and Rezaian, M. A. 2007. A recessive allele (tgr-1) conditioning tomato resistance to geminivirus infection is associated with impaired viral movement. Phytopathology 97:930-937.

Begomoviruses (the family Geminiviridae) are transmitted by the whitefly Bemisia tabaci and contain monopartite or bipartite circular single-stranded (ss)DNA genomes. They have emerged as severe problems in the production of agricultural and horticultural crops worldwide. Here, we report the identification of a tomato breeding line, FLA653, that confers a high level of resistance to Tomato leaf curl virus (TLCV, mo- nopartite). Genetic analysis indicated that the resistance is controlled by a single recessive allele named $\operatorname{tg} r-1$, which is in contrast to previous reports that multiple genetic factors are involved in tomato resistance to begomoviruses. Particle bombardment of an infectious TLCV DNA construct into the detached leaves of FLA653 resulted in the viral replication, but the viral ssDNA accumulated at a much lower level than that in susceptible controls. In situ localization of TLCV in the bombarded leaves suggests that $\operatorname{tg} r-1$ impaired TLCV movement, raising the possibility that it may specify a host factor essential for viral systematic infection. This makes $\operatorname{tg} r-1$ a strong candidate for developing resistance in major crops carrying the gene homologue.
Geminiviruses (the family Geminiviridae) form the secondlargest family of plant viruses and have been classified into four genera (Mastrevirus, Curtovirus, Topocuvirus, and Begomovirus) based on their genome structures, insect vectors, and plant hosts (50). The majority of the Geminiviridae belongs to the genus $\mathrm{Be}$ gomovirus, which are transmitted by the whitefly Bemisia tabaci (Gennadius), and their genomes consist of either one or two circular, single-stranded (ss)DNA species of 2,600 to 2,800 nucleotides (nt) (16). Their genomes contain limited coding capacity and geminiviruses depend on host factors for DNA replication and movement $(17,20)$. Tomato yellow leaf curl virus (TYLCV) contains a monopartite genome and is one of the most widespread and economically important begomoviruses $(24,32,33)$. Tomato leaf curl New Delhi virus (ToLCNDV) contains a bipartite genome, both of which are required for infection (35). In Australia, Tomato leaf curl virus (TLCV) first was reported in the 1970s in the Northern Territory (1). It has a monopartite genome of 2,766 nt that encodes six open reading frames (8). An encapsidated satellite DNA of $682 \mathrm{nt}$, which depends on TLCV for its replication, has been isolated from TLCV-infected tomato plants; however, the satellite DNA does not contribute to the viral pathogennicity (7).

Begomoviruses have emerged as severe problems in a wide range of crops, including cotton, cassava, grain legumes, and vegetables $(3,31)$. Their epidemics have been attributed to their ability to undergo genetic recombination, their association with

Corresponding author: M. A. Rezaian; E-mail address: rezaian@bigpond.net.au

* The $\boldsymbol{e}$-Xtra logo stands for "electronic extra" and indicates that the online version contains supplemental material not included in the print edition. Figures 2, 3, and 4 appear in color online.

doi:10.1094/PHYTO-97-8-0930

(C) 2007 The American Phytopathological Society infectious satellite molecules, and their transmission by polyphagous whitefly genotypes that act as efficient vectors $(3,40,51)$. Geminivirus control often is based on limiting the vector population by insecticides and by physical barriers. However, in severe whitefly infestations, these measures are ineffective. Currently, the most efficient approach to reducing Begomovirus damage to tomato crops (Solanum lycopersicum L., formerly Lycopersicon esculentum Mill.) is the use of resistant cultivars produced by breeding (26).

A practical screening system is essential for identification and introgression of resistance genes into elite tomato cultivars. The use of natural infections in the field is limited by variation in inoculum pressure and onset of infection. Experimental cage inoculation is reliable (23) but time consuming. Agrobacterium-mediated inoculation of infectious viral DNA clones (14) offers an effective alternative when infection efficiency parallels that of whitefly inoculation.

All the commonly grown tomato cultivars are susceptible to tomato-infecting begomoviruses. However, particular accessions of some wild Solanum spp. have been found that are resistant to TYLCV $(36,37,39)$. A commercial $F_{1}$ hybrid (TY20), carrying resistance genes derived from Solanum peruvianum, delayed TYLCV symptom development and its DNA accumulation $(38,44)$. Tomato lines (TY172 and TY197) with strong resistance to TYLCV have been developed from four different accessions of S. peruvianum $(11,27)$. An accession of S. chilense (LA1969) has a high level of resistance to TYLCV (57) and the major tolerance gene $T y-1$ has been integrated into a cultivated tomato (TY52) with barely detectable levels of TYLCV DNA following viral inoculation (30). Another TLCV-India resistant line (H24) was developed by controlled introgression of $S$. habrochaiies (formerly S. hirsutum) to tomato (22). H24-derived resistance was mapped to the long arm of tomato chromosome 11 (19) and subsequently named $T y-2$ (18). $T y-3$, a partially dominant gene for TYLCV re- 
sistance, was introgressed into tomato from $S$. chilense accession LA2779 and mapping studies indicated that $T y-3$ is linked to $T y-1$ on the top of the chromosome 6 (21). A recessive allele (tcm-1) derived from the commercial hybrid 'Tyking' was reported to condition resistance to Tomato chlorotic mottle virus, a bipartite begomovirus from Brazil (13). Some TYLCV tolerance also has been found in certain $S$. pimpinellifolium accessions (53), although resistance from this species is not commonly used in commercial cultivars.

Despite the similarity in the naming of TLCV and TYLCV, there are significant differences between DNA sequences of these viruses. TLCV is more closely related to African cassava mosaic virus (ACMV) than to TYLCV $(8,24)$. As yet, a source of natural resistance to TLCV has not been identified. We report here an extensive screening of tomato breeding lines, wild Solanum accessions, and tomato cultivars for resistance to TLCV. We identified a tomato breeding line (FLA653) that exhibited strong resistance to TLCV infections. Our data suggest that the resistance is controlled by a single recessive allele (named $\operatorname{tg} r-1$ ) and is effective against TLCV and operates by impairing the viral movement. This study offers the potential for further developing resistance in major crops carrying the gene homologue.

\section{MATERIALS AND METHODS}

Solanum accessions. The tomato breeding lines, tomato cultivars, and wild Solanum spp. used in this study are listed in Table 1. Selection of these genotypes was based on their resistance to TYLCV. All plants were grown under glasshouse conditions at 25 to $30^{\circ} \mathrm{C}$.

Whitefly-mediated inoculation. Thirty individual plants of each genotype were challenged by B. tabaci biotype B inoculation as described (48). Ten tomato seedlings at the two-leaf stage and two TLCV-infected tomato plants at 30 to 40 days postinoculation (dpi) were placed in a cage with $\approx 300$ whiteflies for 5 days. Plants were lightly disturbed daily to help even distribution of the whiteflies. Symptoms were assessed $30 \mathrm{dpi}$ and the presence of the viral DNA was analyzed by dot blot hybridization.

Agrobacterium-mediated inoculation. Tandem-repeated DNA construct of TLCV (8) in pBin19 was used in this study. Cultures of Agrobacterium tumefaciens C58 carrying the infectious construct were grown at $28^{\circ} \mathrm{C}$ for $48 \mathrm{~h}$ and diluted to a concentration of optical density at $600 \mathrm{~nm}=0.1$ using the culture medium (agroinoculation). Twenty-one plants of each genotype at the four- to five-leaf stage were inoculated by injection of $2 \mu \mathrm{l}$ of the diluted culture at four different leaf nodes.

Grafting-mediated inoculation. TLCV-infected tomato plants (Ailsa Craig) were used as the rootstock to "V-graft" stem segments from healthy test plants. Developing leaves of the scions and rootstock were analyzed by dot blot hybridization to test the presence of TLCV 30 days post-grafting (dpg). All graft inoculation experiments were done in triplicate.

TLCV symptom severity rating. Disease incidence and severity were scored 30 dpi using an arbitrary scale of 0 to 4 , where $0=$ no visible symptoms, $1=$ slight curling, $2=$ mild yellowing or curling, 3 = curling and yellowing, and $4=$ severe curling and yellowing.

Virus detection by dot blot hybridization. Developing leaves $(50$ to $100 \mathrm{mg}$ ) from individual plants were homogenized in $0.5 \mathrm{M} \mathrm{NaOH}$ at a ratio of $4 \mu \mathrm{l}$ of buffer per $1 \mathrm{mg}$ of fresh leaf tissue. TLCV DNA was detected by dot blot hybridization as described (48). Quantification of radioactive signals was achieved by exposing the hybridized membranes to a PhosphorImager screen (Molecular Dynamics, Sunnyvale, CA). The PhosphorImager counts were converted to DNA concentrations by comparing with serial dilutions of TLCV DNA of known concentrations.

Tomato crosses and self-pollination. The flowers of the maternal line CLA2418A (geminivirus susceptible) were emasculated before their anthers shed pollen. The mature anthers of the paternal line FLA653 were placed on the pistils of the emasculated CLN2418A flowers and the shoots covered with paper bags. After fruit maturation, the $\mathrm{F}_{1}$ seed were removed, washed with $5 \% \mathrm{HCl}$ followed by three rinses with water, dried at room temperature, and stored at $4{ }^{\circ} \mathrm{C}$ in a sealed container over dry silica gel. One $\mathrm{F}_{1}$ plant was self-pollinated and $45 \mathrm{~F}_{2}$ progenies were produced. The $\mathrm{F}_{2}$ lines were self-pollinated to produce $\mathrm{F}_{3}$ families. Then, 9 to $16 \mathrm{~F}_{3}$ progenies of each $\mathrm{F}_{2}$ line were agroinoculated to assess TLCV resistance in the $\mathrm{F}_{2}$ population.

Virus replication assay by particle bombardment. Expanding tomato leaves were placed on a piece of wet filter paper in a 9-cm petri dish and bombarded with gold particles coated with the infectious TLCV DNA construct as described (46). The leaves were kept in the dark at $25^{\circ} \mathrm{C}$ overnight and then maintained for another 2 days with a photoperiod of $16 \mathrm{~h}$ in a growth room. Total nucleic acid was extracted as described (49) and treated with RNase A (40 $\mu \mathrm{g} / \mathrm{ml})$. DNA (5 $\mu \mathrm{g} / \mathrm{lane})$ was analyzed in a $1.2 \%$ agarose gel containing ethidium bromide $(0.5 \mu \mathrm{g} / \mathrm{ml})$ to facilitate

TABLE 1. Solanum genotypes used in this study

\begin{tabular}{|c|c|c|c|}
\hline Name used in this study & Full name, accession & Source of resistance ${ }^{a}$ & Reference, source ${ }^{b}$ \\
\hline $\mathrm{AC}$ & Ailsa Craig & None & Moles Seeds, Essex, UK \\
\hline Avinash-2 & Avinash-2 & Unknown & Novartis Seed \\
\hline CLN2116 & CLN2116DC1F1-180-31 & $\mathrm{H} 24(T y-2)$ & AVRDC \\
\hline CLN2026D & CLN2026D & None & AVRDC \\
\hline FLA456 & FLA456-4 & Solanum chilense (LA2779) and Tyking & J. W. Scott, UFL \\
\hline FLA478 & FLA478-6-4 & S. chilense (LA1938), Tyking & J. W. Scott, UFL \\
\hline FLA505 & FLA505 & S. chilense (LA1969), Tyking and Fiona & J. W. Scott, UFL \\
\hline FLA658 & FLA658-SBK-6 & S. chilense (LA1969), Tyking & J. W. Scott, UFL \\
\hline FLA699 & FLA699sp. & S. chilense (LA1938) and S. pimpinellifolium (PI211840) & J. W. Scott, UFL \\
\hline Gempride & Gempride & Unknown & Peto Hybrid \\
\hline $\mathrm{H} 24$ & $\mathrm{H} 24$ & B6013 (S. habrochaites) & 19,22 \\
\hline S. pennellii & $\ldots$ & S. pennellii & S. J. Barker, UWA \\
\hline TY52 & TY52 & Ty-1 from S. chilense (LA1969) & 30,58 \\
\hline TY172 & TY172 & S. peruvianum L. Mill (PI 126926, PI 126930, PI 390681, and LA441) & 11,27 \\
\hline
\end{tabular}

a Tyking from Sluis and Groot, The Netherlands; and Tyking and Fiona from Royal Sluis, The Netherlands.

${ }^{\mathrm{b}}$ AVRDC = Asian Vegetable Research and Development Center, Taiwan, R.O.C.; UFL = University of Florida, United States; and UWA = University of Western Australia. 
separation of the ssDNA and double-stranded (ds)DNA forms. The DNA was blotted onto a nylon membrane using $0.4 \mathrm{M} \mathrm{NaOH}$ or $10 \times \mathrm{SSC}(1 \times \mathrm{SSC}$ is $0.15 \mathrm{M} \mathrm{NaCl}$ plus $0.015 \mathrm{M}$ sodium citrate) as transfer media and hybridized with $\alpha^{32} \mathrm{P}$-labeled TLCV DNA probes as described (43).

Random amplified polymorphic DNA analysis. Random amplified polymorphic DNA (RAPD) amplifications were performed using 10-mer oligonucleotides as described (56) with some modifications. Polymerase chain reaction (PCR) reactions were per-

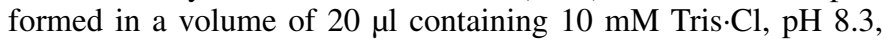
$50 \mathrm{mM} \mathrm{KCl}, 1.5 \mathrm{mM} \mathrm{MgCl}_{2}, 0.2 \mathrm{mM}$ dNTPs, $0.2 \mu \mathrm{M}$ primer, $50 \mathrm{ng}$ of genomic DNA, and $0.25 \mathrm{U}$ of Taq DNA polymerase (Invitrogene). PCR products were separated in a $0.9 \%$ agarose gel and visualized by ethidium bromide staining.

In situ hybridization. Leaf tissues were fixed in $0.05 \mathrm{M}$ phosphate buffer containing $4 \%$ paraformaldehyde, $0.25 \%$ glutaraldehyde, and $1 \mathrm{mM} \mathrm{1,4-dithiothreitol} \mathrm{for} 2 \mathrm{~h}$ at $4{ }^{\circ} \mathrm{C}$ and subsequently dehydrated by an ethanol series and embedded in buty-methylmethacrylate as described previously (42). Tissue sections, 6 to $8 \mu \mathrm{m}$ thick, were placed on silane-coated slides (ProSciTech, Thuringowa Central, Australia). Prehybridization, hybridization, and posthybridization were performed as describe (15). Probes were detected using Western Blue (Promega Corp., Madison, WI) substrates. The slides were dehydrated, mounted in entellan mounting medium, and observed under a light microscope (Axioscope2, Carl Zeiss, Jena, Germany).

\section{RESULTS}

Screening for resistance by whitefly, grafting, and Agrobacterium-mediated inoculations. A range of tomato genotypes (Table 2) was screened for resistance to TLCV using whiteflymediated inoculation under biosecurity containment with 30 plants per genotype. Symptom observation at 30 dpi revealed significant variations between genotypes (Table 2). Under the transmission condition, the susceptible cv. Ailsa Craig showed 100\% infection. However, some of the genotypes assessed for resistance contained as few as 4 symptomatic plants in the 30 replicates (Table 2). Notably, the breeding lines (FLA505 and FLA591) showed much lower infection incidences than those of H24 and TY52, which have been reported to be resistant to TYLCV $(22,30)$.

The Florida breeding lines (FLA505, FLA591, and FLA699), $\mathrm{H} 24$, and Ailsa Craig also were assessed for resistance to TLCV by grafting their healthy scions onto TLCV-infected rootstocks. The presence of TLCV in new leaves from both scions and in rootstocks was tested by dot blot hybridization at $30 \mathrm{dpg}$. TLCV DNA accumulation in FLA505 and FLA591 was significantly lower than that in FLA699, H24, and Ailsa Craig (Fig. 1), which is consistent with the resistance levels assessed by whitefly-mediated inoculation.

TABLE 2. Screening tomato genotypes for Tomato leaf curl virus resistance by whitefly inoculation

\begin{tabular}{lc}
\hline Genotype & Infection incidence $^{\mathrm{a}}$ \\
\hline FLA505 & $4 / 30$ \\
FLA591 & $7 / 30$ \\
H24 & $11 / 30$ \\
FLA699 & $15 / 30$ \\
FLA456 & $16 / 30$ \\
CLN2026D & $18 / 30$ \\
TY52 & $21 / 30$ \\
CLN2116 & $22 / 30$ \\
Gempride & $22 / 30$ \\
Avinash 2 & $24 / 30$ \\
Ailsa Craig (positive control) & $30 / 30$ \\
Ailsa Craig (negative control & $0 / 5$ \\
\hline
\end{tabular}

a Number of symptomatic plants over number of inoculated plants at 30 days postinoculation.
Although screening tomato genotypes by whitefly or graftingmediated inoculations was highly desirable, it was restrictive and time consuming. Therefore, we investigated whether the observed resistance by whitefly and grafting inoculations could be reproduced by agroinoculation. Using the conditions outlined in Materials and Methods, we challenged the first five accessions listed in Table 3 using TLCV agroinoculation. Symptom development and viral DNA accumulation were assessed at 30 dpi (Table 3). Ailsa Craig and $\mathrm{H} 24$ developed severe symptoms and accumulated a high level of viral DNA. However, FLA505 and FLA591 showed milder symptoms and accumulated much lower levels of TLCV DNA. These results indicated that, under the conditions used, the rates of infectivity by agroinoculation were consistent with those of whitefly and grating inoculations. In a further screening of the tomato lines, the nine accessions listed in Table 3 were challenged by TLCV agroinoculation. Two Florida breeding lines (FLA653 and FLA658) remained symptomless and contained no detectable levels of viral DNA at $30 \mathrm{dpi}$. TY172 and TY197, which showed resistance to TYLCV (27), accumulated low levels of TLCV DNA and exhibited mild symptoms. The other lines tested were susceptible to TLCV. This suggested that the Florida tomato breeding lines were promising sources of TLCV resistance. Thus, the tomato breeding line FLA653 was chosen for further characterization. To analyze the genetics of

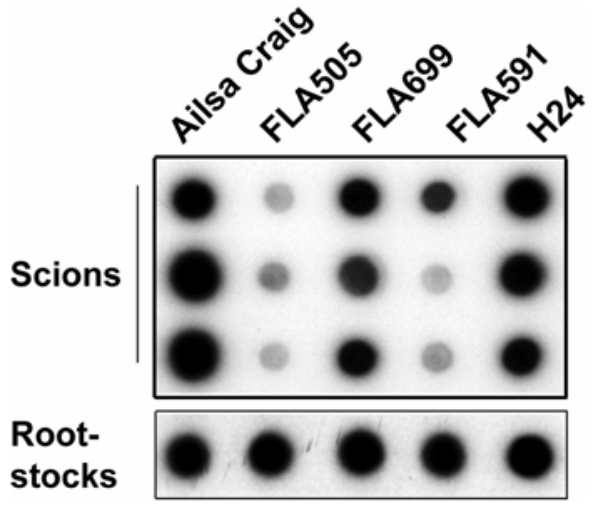

Fig. 1. Dot blot hybridization showing the levels of Tomato leaf curl virus (TLCV) DNA in grafted plants. Healthy scions of Ailsa Craig, FLA505, FLA699, FLA591, and H24 were grafted onto TLCV-infected rootstocks. The presence of TLCV was tested in the newly developed leaves from the scions and rootstocks at 30 days postinoculation. Each dot represents an independent plant sample.

TABLE 3. Screening tomato genotypes for Tomato leaf curl virus (TLCV) resistance by agroinoculation

\begin{tabular}{lcc}
\hline Genotype $^{\mathrm{a}}$ & Symptoms $^{\mathrm{b}}$ & $\begin{array}{c}\text { Viral DNA accumulation } \\
\text { (pg of DNA/mg of fresh leaf) }\end{array}$ \\
\hline Ailsa Craig & $3.3 \pm 0.7$ & $4.7 \pm 0.7$ \\
FLA505 & $0.2 \pm 0.6$ & $0.9 \pm 1.1$ \\
FLA699 & $0.7 \pm 0.5$ & $5.1 \pm 1.0$ \\
FLA591 & $0.6 \pm 0.5$ & $2.0 \pm 1.6$ \\
H24 & $3.2 \pm 0.5$ & $5.1 \pm 1.2$ \\
FLA653 & $0.0 \pm 0.0$ & $0.0 \pm 0.0$ \\
FLA658 & $0.0 \pm 0.0$ & $0.0 \pm 0.0$ \\
FLA478 & $0.1 \pm 0.1$ & $0.5+0.3$ \\
TY172 & $0.1 \pm 0.0$ & $1.7 \pm 0.0$ \\
TY197 & $2.0 \pm 0.5$ & $6.3 \pm 2.0$ \\
Solanum chilense (LA1969) & $0.1 \pm 0.0$ & $6.0 \pm 0.0$ \\
S. pennellii & $3.5 \pm 0.6$ & $5.3+1.4$ \\
76A & $3.8+0.6$ & $6.3 \pm 2.3$ \\
CLN2418A & $4.0 \pm 0.5$ & $8.7 \pm 2.3$
\end{tabular}

a Twenty-one plants of each genotype were agroinoculated with the infectious TLCV construct.

b Plants were scored at 30 days postinoculation (dpi) with a 5-class scale.

c The viral DNA accumulation (30 dpi) was estimated by dot blot analysis and quantified by a PhosphorImager using DNA standards. 
FLA653 resistance to TLCV, it was crossed with the sensitive cultivar CLN2418A as a female parent. The latter line has a green stem color conditioned by a recessive gene $a h$, anthocyaninless of Hoffman, whereas FLA653 has purple stem color due to $A H$, the dominant gene. This provided a visual marker for distinguishing self-pollinated $F_{1}$ seedlings from those derived from FLA653. The hybridity of $F_{1}$ seedlings was checked by the light-purple stem color and confirmed by RAPD analysis (data not shown). Six $\mathrm{F}_{1}$ plants of the cross between CLN2418A and FLA653 were agroinoculated with TLCV and all developed symptoms that appeared milder (Fig. 2C) than those of TLCV-infected CLN2418A plants (Fig. 2A) and accumulated high levels of the viral DNA (Fig. 2D). However, there was no statistical difference in symptom severity and virus accumulation level between the $F_{1}$ and susceptible parental plants. As observed before, FLA653 remained symptomless and accumulated no detectable levels of TLCV DNA (Fig. 2B and D). These results suggested that FLA653 resistance to TLCV was recessive.

To further analyze the segregation of TLCV resistance and to establish a mapping population, one $\mathrm{F}_{1}$ plant from the cross CLN2418A $\times$ FLA653 was self-pollinated and $F_{2}$ seed were obtained. The $\mathrm{F}_{2}$ plants (a total of 45) were developed into $\mathrm{F}_{3}$ families as shown in Figure 2. In all, 9 to $16 \mathrm{~F}_{3}$ plants from each $\mathrm{F}_{2}$ line were agroinoculated with TLCV to assess the resistance in the $45 \mathrm{~F}_{2}$ progenies. Both $\mathrm{F}_{2}$ and $\mathrm{F}_{3}$ segregation data for TLCV
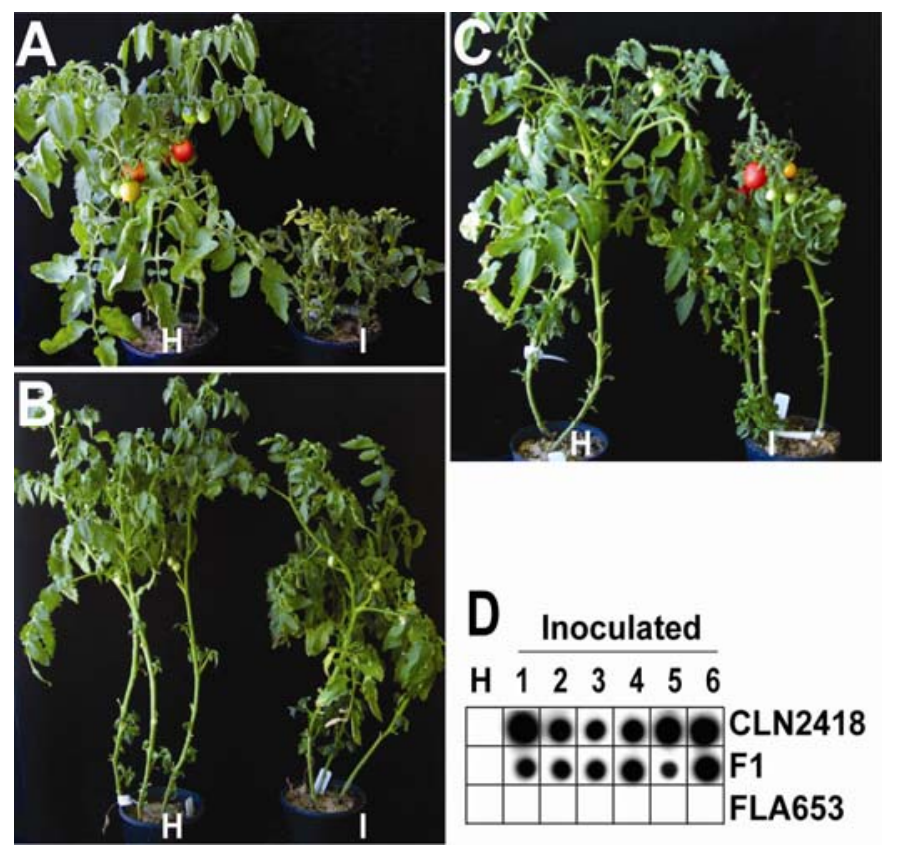

Fig. 2. Segregation of Tomato leaf curl virus (TLCV) resistance in the tomato line FLA653. Photographs of healthy $(\mathrm{H})$ and infected (I) plants of A, CLN2418A, B, FLA653, and $\mathbf{C}$, their $F_{1}$ progeny were taken at 60 days postinoculation. The presence of TLCV in developing leaves of plants in panels $\mathbf{A}$ to $\mathbf{C}$ was tested by $\mathbf{D}$, dot blot hybridization. The numbers (1 to 6 ) represent plant replicates. resistance closely fit into a 3:1 ratio of susceptible/resistant plants (Table 4). Based on the segregation data from individual $F_{3}$ families, we further classified the $45 \mathrm{~F}_{2}$ lines into homozygous susceptible, segregating, and homozygous resistant groups, which statistically agreed with a 1:2:1 segregation ratio (Table 4). These results suggest that FLA653 resistance to TLCV is controlled by a single recessive allele, which we named tomato geminivirus resistance allele 1 ( $\operatorname{tg} r-1)$.

Allele tgr-1 impairs TLCV systematic movement. The lack of symptom development and viral accumulation in the FLA653 plants inoculated with TLCV raised the possibility that tgr-1 either suppresses viral replication or impairs its movement from the sites of inoculation. To test these possibilities, detached leaves of FLA653 and CLN2418A were bombarded with the infectious TLCV DNA construct in triplicates. DNA gel blot analysis of these lines 3 dpi showed that FLA653 supported TLCV accumulation, but at lower levels compared with that of CLN2418A (Fig. $3 \mathrm{~A})$. It was noted that the viral dsDNA forms (including open circular and supercoiled) were not significantly different between these two lines (Fig. 3A). The identity of the viral DNA forms was confirmed by blotting under nondenaturing conditions using $10 \times$ SSC. The results indicated a much lower level of ssDNA accumulated in FLA653 than in CLN2418A (Fig. 3B). These observations demonstrate that $\operatorname{tg} r-1$ does not prevent TLCV replication at sites of inoculation, but somehow restricts the viral ssDNA accumulation.

We also carried out in situ localization of TLCV DNA in the detached leaves of FLA653 and CLN2418A bombarded with gold particles coated with TLCV infectious DNA 3 dpi. The viral DNA was present abundantly in the phloem cells in tissue sections from CLN2418A (Fig. 3D). However, TLCV was sparsely detected in the phloem tissue of FLA653 (Fig. 3E). No cross hybridization signals were detected in the healthy control (Fig. 3C). This result indicates that $\operatorname{tg} r-1$ impaired TLCV cell-to-cell movement.

To investigate whether tgr-1 impairs the viral long-distance translocation, we conducted a double-grafting experiment. As a control, a healthy scion of CLN2418A was grafted between a healthy scion of CLN2418A and a TLCV-infected rootstock (Fig. 4C). Severity of symptoms and the level of TLCV accumulation were similar in both the upper and the intermediate scions at $30 \mathrm{dpg}$ (Fig. 4C and D). When a healthy scion of FLA653 was grafted between a healthy scion of the susceptible CLN2418A and a TLCV-infected rootstock (Fig. 4A), severity of symptoms and the level of TLCV DNA in the upper susceptible scion were significantly lower (Fig. 4A and B) than those in the control. Trace levels of TLCV DNA were detected in the FLA653 intermediate scions, but no symptoms were observed (Fig. 4A and B). Therefore, our results suggest that $\operatorname{tg} r-1$ also impaired TLCV long-distance translocation.

\section{DISCUSSION}

Plants defense against pathogens involves a range of mechanisms. A well-characterized resistance mechanism known as the gene-for-gene response is governed by specific interactions between the pathogen avirulence (avr) gene and the corresponding

TABLE 4. Genetic resistance to Tomato leaf curl virus (TLCV) in FLA653 progenies

\begin{tabular}{|c|c|c|c|c|c|c|c|c|}
\hline \multirow[b]{2}{*}{ Crosses } & \multicolumn{5}{|c|}{ Number of lines or plants ${ }^{a}$} & \multirow[b]{2}{*}{$\chi^{2}(1: 3)$} & \multirow[b]{2}{*}{$\chi^{2}(1: 2: 1)$} & \multirow[b]{2}{*}{$P$ value } \\
\hline & Res & Sus & Hzy res & Seg & Hzy sus & & & \\
\hline $\mathrm{F}_{2}(\mathrm{CLN} 2418 \mathrm{~A} \times \mathrm{FLA653})^{\mathrm{b}}$ & 11 lines & 34 lines & $\ldots$ & $\ldots$ & $\ldots$ & 0.007 & .. & 0.93 \\
\hline $\mathrm{F}_{3}(\mathrm{CLN} 2418 \mathrm{~A} \times \mathrm{FLA653})$ & 178 plants & 486 plants & $\ldots$ & $\ldots$ & $\ldots$ & 1.16 & $\ldots$ & 0.28 \\
\hline $\mathrm{F}_{2}(\mathrm{CLN} 2418 \mathrm{~A} \times \mathrm{FLA658})^{\mathrm{c}}$ & $\ldots$ & $\ldots$ & 11 lines & 28 lines & 6 lines & $\ldots$ & 3.8 & 0.15 \\
\hline
\end{tabular}

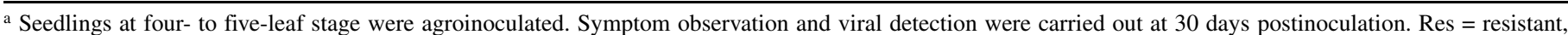
Sus $=$ susceptible, Hzy = homozygous, and Seg = segregating.

b Data were based on agroinoculation results from $\mathrm{F}_{3}$ families ( 9 to 16 plants of each line tested).

c Derived from the $\mathrm{F}_{3}$ family segregation data of TLCV resistance. 
resistance $(R)$ gene of the plant (5). Plants also have evolved an adaptive defense mechanism known as RNA silencing to suppress foreign genetic elements $(54,55)$. A passive mechanism allowing plants to escape pathogen attack is the lack of a specific host factor required by the virus for its replication or spread (6). The translation initiation factor (elF4E) has been found associated with the pepper recessive resistance against Potato virus $Y$ (34, 45). Here, we demonstrate that a tomato breeding line, FLA653, with a recessive allele $(\operatorname{tg} r-1)$ confers a high level of resistance to TLCV by a process that appears to impair viral movement.

The tomato line FLA653 produced no viral symptoms and accumulated no detectable levels of viral DNA (Table 3) after agroinoculation. The use of agroinoculation in screening resistance has been questioned because it might lead to breakdown of certain natural resistances (25). The optimized agroinoculation used here produced infection incidences (Table 3) comparable to those obtained by whitefly inoculation (Table 2) and graftingmediated inoculation (Fig. 1). The strong resistance we report here withstands agroinoculation.

To understand the mechanism of FLA653 resistance to TLCV, we crossed FLA653 with CLN2418A, a cultivar highly suscepti- ble to TLCV. All six $F_{1}$ seedlings agroinoculated with TLCV showed milder symptoms and accumulated high levels of the viral DNA (Fig. 2C and D). Due to the lack of a reciprocal cross between CLN2418A and FLA653, we cannot exclude the possibility that some other genetic factors also are involved in FLA653 resistance to TLCV. However, the results with the segregation data of TLCV resistance in both $\mathrm{F}_{2}$ and $\mathrm{F}_{3}$ populations led us to conclude that FLA653 resistance to TLCV is under the control of a single recessive allele.

Normally, tomato resistance to geminiviruses is controlled by multiple genes (26). The TYLCV resistance in tomato line TY172, derived from $S$. peruvianum, is controlled by at least three interacting genes (11). In a tomato breeding line (902) derived from S. habrochaites (LA1777 and LA386), resistance to TYLCV is controlled by two or three additive recessive genes (52). The resistance in $S$. chilense accession LA1969 is controlled by a major, partially dominant gene termed $T y-1$ and at least two more modifier genes (58). However, we found that FLA653 resistance to TLCV was controlled by a single recessive allele (tgr- 1 ). According to its pedigree information, FLA653 has been derived from a cross involving two pollen sources of S. chilense (LA2779) and
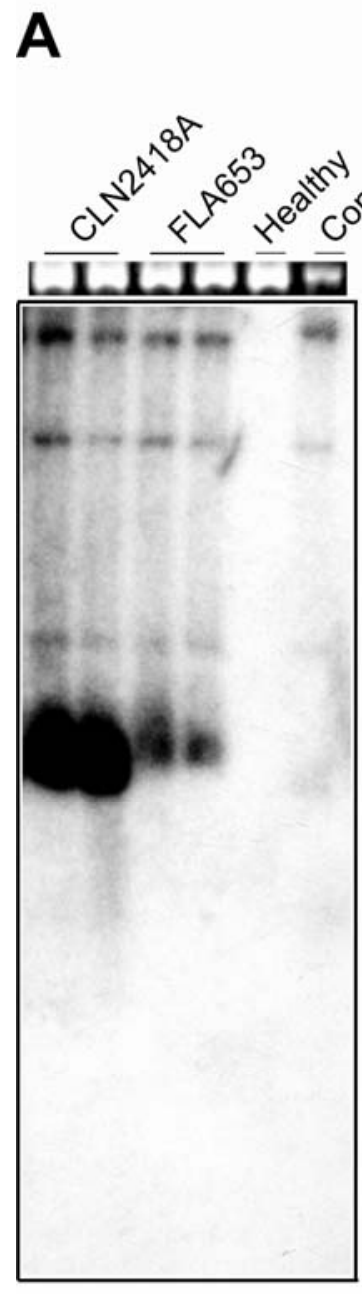

$\begin{array}{llllll}1 & 2 & 3 & 4 & 5 & 6\end{array}$
B
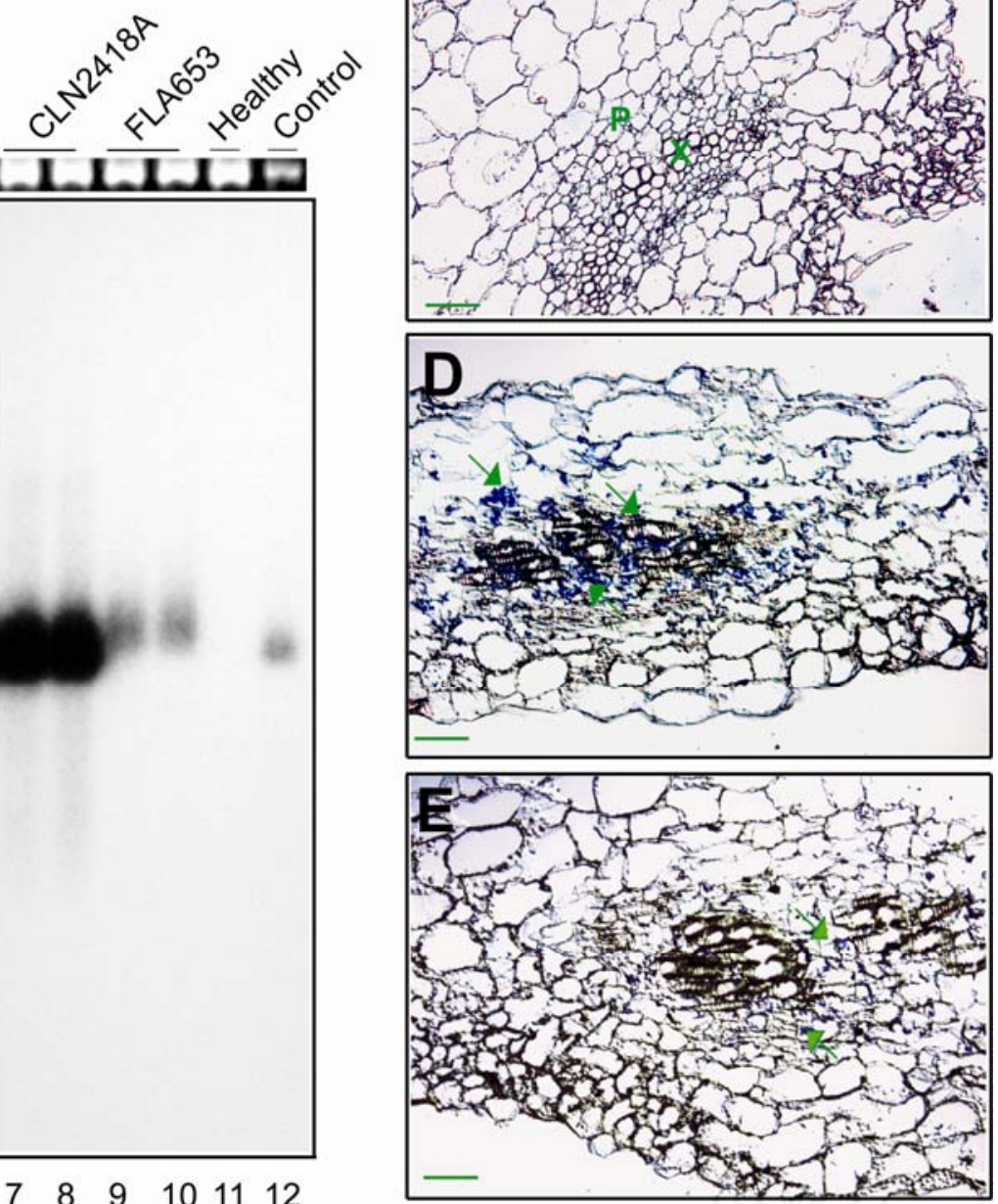

Fig. 3. A and B, DNA gel-blot analysis showing Tomato leaf curl virus (TLCV) replication in the detached leaves of CLN2418A and FLA653 at 3 days postinoculation by particle bombardment. Two of the three replicates are shown. Noninfected (Healthy) and TLCV systemically infected (Control) tomato plants were included. The total DNA loading of the positive control was much lower than those of resistant lines inoculated via particle bombardment. DNA blotting was either by $\mathbf{A}, 0.4 \mathrm{M} \mathrm{NaOH}$ or $\mathbf{B}, 10 \times \mathrm{SSC}\left(1 \times \mathrm{SSC}\right.$ is $0.15 \mathrm{M} \mathrm{NaCl}$ plus $0.015 \mathrm{M}$ sodium citrate). The viral DNA forms were detected by hybridization with a ${ }^{32} \mathrm{P}-$ labeled TLCV probe. OC: open circular double-stranded (ds)DNA; SC: supercoiled ds replicative form DNA; and SS: single-stranded DNA. C to E, In situ localization of TLCV DNA in detached leaves of D, CLN2418A and E, FLA653 bombarded by gold particles coated with TLCV DNA. C, Healthy leaves were used as a control. The sections were hybridized with digoxigenin (DIG)-labeled, complementary-sense ssRNA from the V2 open reading frame and viewed with differential interference contrast optics. Hybridization signals are indicated by arrows. Bars = $100 \mu \mathrm{m}$; M: mesophyll; P: phloem; and X: xylem. 
Tyking. The partially dominant gene $T y-3$ was derived from LA2779 and confers high levels of resistance to TYLCV and some resistance to a bipartite geminivirus, Tomato mottle virus (21). Tyking may have contributed resistance to FLA653, although the genetics of geminivirus resistance in Tyking is not well understood because it is a commercial hybrid. The tcm-1 gene conditioning resistance to the Brazilian geminivirus Tomato chlorotic mottle virus detected in the breeding line TX 468-RG that was derived from Tyking (13) and this gene also might be present in FLA653. The virus resistance in Tyking led to impairment of virus movement in the phloem (9), which is similar to the resistance mechanism we detected in FLA653.

Geminiviruses rely extensively on host factors to amplify their genomes $(16,17)$ and to spread in plants $(12,20)$. Mutation of a host factor involved in geminivirus infection processes may block the viral life cycle. For example, it has been found that a recessive allele in Arabidopsis confers resistance to Beet curly top virus (Geminiviridae) by impairing the viral movement (28). It is tempting to speculate that $\operatorname{tg} r-1$ might be a mutated gene encoding a host factor required for TLCV infection. Our TLCV transient replication and movement assays (Figs. 3 and 4) indicate that $\operatorname{tg} r-1$ impaired TLCV movement. Geminiviral movement involves specific viral genes, including the coat protein, and is mediated by host-interacting proteins that facilitate viral movement across the cell barrier. Recently, two host factors, an acetyltransferase (AtNSI) from Arabidopsis $(29,41)$ and a reversibly glycosylated protein (SIUPTG1) from tomato (47), have been isolated that specifically interact with movement proteins encoded by Cabbage leaf curl virus and TLCV, respectively. We have no evidence to link $\operatorname{tg} r-1$ with either SIUPTGI or with an AtNSI gene homologue. However, these host proteins are potential candidates for elucidating the molecular basis of $\operatorname{tg} r-1$ resistance.

In this study, TY172 was classified as a TLCV-resistant genotype, because a low level of TLCV DNA was detected in inoculated plants but no symptoms were observed. This observation is consistent with the report that TY172 is a symptomless carrier of TYLCV (11). Because TY172 resistance originates from L. peruvianum $(11,27)$, it potentially can be used as additional breeding material to pyramid resistance to TLCV. Different geminivirus resistance mechanisms have been found in tomato, including tolerance (high virus concentrations with moderate symptom expression) to reduction in virus replication, accumulation, and spread $(4,9,30)$. Given the diversity of geminiviruses worldwide (10) and regionally, the breeding of cultivars with stable resistance poses a great challenge to tomato breeders. The realization that almost all geminivirus resistance in tomato is derived from wild species and that introgression of this resistance into tomato requires years of work argues for careful stewardship of resistance genes. A better understanding of the mechanisms of genes resistant to geminiviruses would lead to the identification of genes with different mechanisms that have the potential to complement each other. Combining carefully targeted resistance genes into cultivars by marker-assisted selection or by crossing hybrid parental lines carrying different resistance genes may result in cultivars with prolonged resistance.

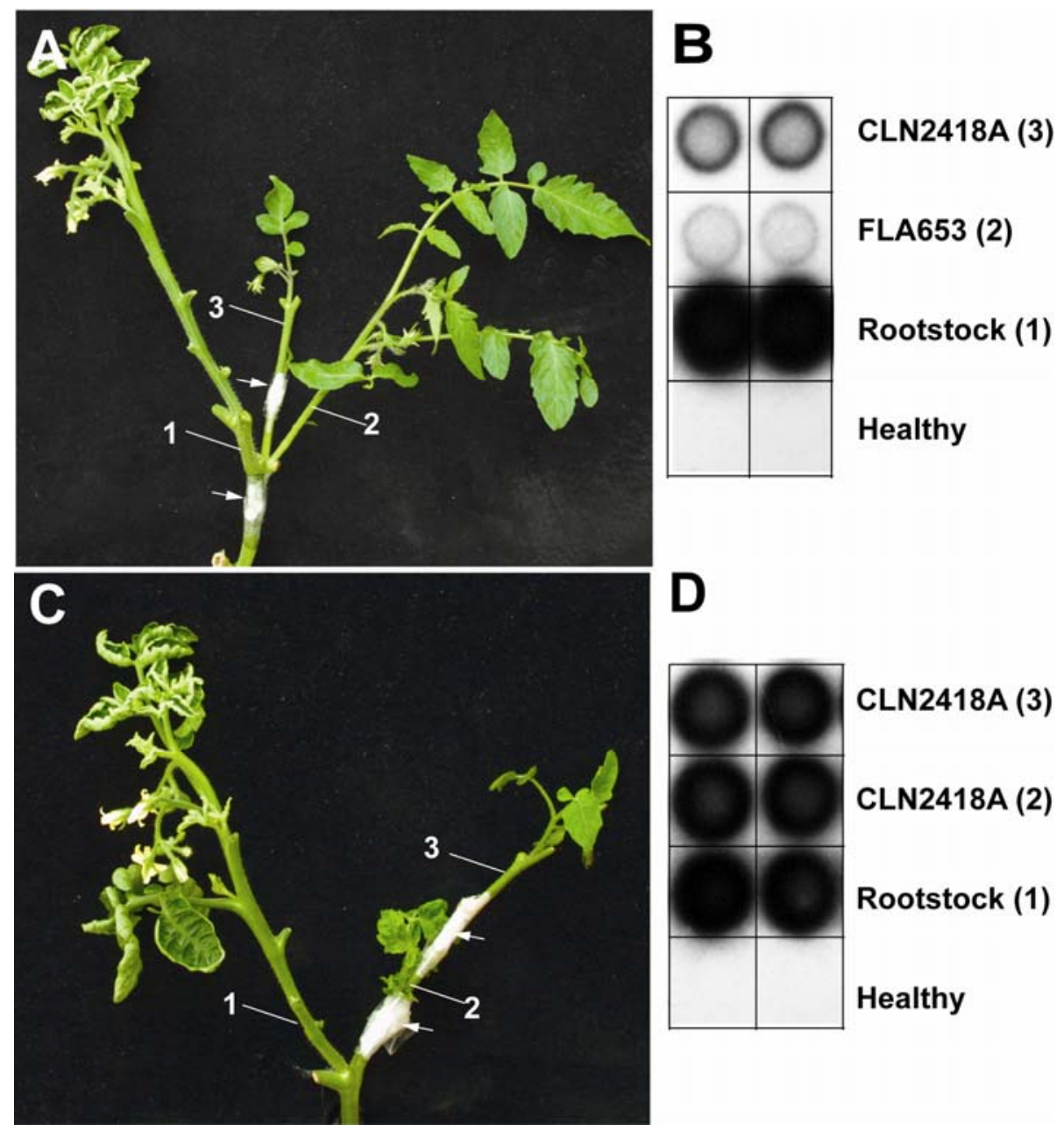

Fig. 4. Tomato leaf curl virus (TLCV) long-distance movement through FLA653 stems tested by double grafting. Healthy scions from either A, 2, FLA653 or C, 2, CLN2418A were grafted onto A and C, 1, TLCV-infected rootstocks. A and C, 3, The second scions from CLN2418A were grafted onto the first scion. The graft unions are indicated by arrows. The photos were taken at 30 days post-grafting (dpg). B and D, TLCV DNA accumulation in the newly developed leaves for the indicated scions and rootstocks determined by dot-blot hybridization at $30 \mathrm{dpg}$. The sample numbers correspond to the numbers in panels $\mathbf{A}$ and $\mathbf{C}$. 
Geminiviruses remain a major threat to world crop production $(3,31,51)$. Given the challenge of transgenic resistance to geminiviruses (2) and the issue of market acceptance for genetically modified tomato, the highly effective resistance allele reported here offers significant potential for geminivirus control. Further characterization and cloning of $\operatorname{tgr}-1$ may contribute to understanding geminivirus movement in planta and facilitate the search for the homologue in other crops, such as cotton, where engineering resistance by genetic modification is acceptable.

\section{ACKNOWLEDGMENTS}

This work was supported by Horticulture Australia grant VX99003 to A. Rezaian. M. S. Rasheed was supported by an ACIAR/John Allwright Fellowship. We thank J. Stonor and P. Hart for assistance in TLCV screening and whitefly inoculation experiments, and J. W. Scott of the University of Florida for generously providing seed of his tomato breeding lines.

\section{LITERATURE CITED}

1. Behjatnia, S. A. A., Dry, I. B., Krake, L. R., Conde, B. D., Connelly, M. I., Randles, J. W., and Rezaian, M. A. 1996. New Potato spindle tuber viroid and Tomato leaf curl geminivirus strains from a wild Solanum sp. Phytopathology 86:880-886.

2. Bian, X. Y., Rasheed, M. S., Seemanpillai, M. J., and Rezaian, M. A. 2006. Analysis of silencing escape of Tomato leaf curl virus: An evaluation of the role of DNA methylation. Mol. Plant-Microbe Interact. 19:614624.

3. Boulton, M. I. 2003. Geminiviruses: Major threats to world agriculture. Ann. Appl. Biol. 142:143-143.

4. Czosnek, H., Kheyrpour, A., Gronenborn, B., Remetz, E., Zeidan, M., Altman, A., Rabinowitch, H. D., Vidavsky, S., Kedar, N., Gafni, Y., and Zamir, D. 1993. Replication of Tomato yellow leaf curl virus (TYLCV) DNA in agroinoculated leaf-disks from selected tomato genotypes. Plant Mol. Biol. 22:995-1005.

5. Dangl, J. F., and Jones, J. D. G. 2001. Plant pathogens and integrated defenses to infection. Nature 411:826-833.

6. Diaz-Pendon, J. A., Truniger, V., Nieto, C., Garcia-Mas, J., Bendahmane, A., and Aranda, M. A. 2004. Advances in understanding recessive resistance to plant viruses. Mol. Plant Pathol. 5:223-233.

7. Dry, I. B., Krake, L. R., Rigden, J. E., and Rezaian, M. A. 1997. A novel subviral agent associated with a geminivirus: the first report of a DNA satellite. Proc. Natl. Acad. Sci. USA 94:7088-7093.

8. Dry, I. B., Rigden, J. E., Krake, L. R., Mullineaux, P. M., and Rezaian, M. A. 1993. Nucleotide sequence and genome organization of Tomato leaf curl geminivirus. J. Gen. Virol. 74:147-151.

9. Fargette, D., Leslie, M., and Harrison, B. D. 1996. Serological studies on the accumulation and localisation of three tomato leaf curl geminiviruses in resistant and susceptible Lycopersicon species and tomato cultivars. Ann. Appl. Biol. 128:317-328.

10. Fauquet, C. M., Bisaro, D. M., Briddon, R. W., Brown, J. K., Harrison, B. D., Rybicki, E. P., Stenger, D. C., and Stanley, J. 2003. Revision of taxonomic criteria for species demarcation in the family Geminiviridae, and an updated list of begomovirus species. Arch. Virol. 148:405-421.

11. Friedmann, M., Lapidot, M., Cohen, S., and Pilowsky, M. 1998. Novel source of resistance to Tomato yellow leaf curl virus exhibiting a symptomless reaction to viral infection. J. Am. Soc. Hortic. Sci. 123:1004-1007.

12. Gilbertson, R. L., Sudarshana, M., Jiang, H., Rojas, M. R., and Lucas, W. J. 2003. Limitations on geminivirus genome size imposed by plasmodesmata and virus-encoded movement protein: insights into DNA trafficking. Plant Cell 15:2578-2591.

13. Giordano, L. B., Silva-Lobo, V. L., Santana, F. M., Fonseca, M. E. N., and Boiteux, L. S. 2005. Inheritance of resistance to the bipartite Tomato chlorotic mottle begomovirus derived from Lycopersicon esculentum cv. 'Tyking'. Euphytica 143:27-33.

14. Grimsley, N., Hohn, B., Ramos, C., Kado, C., and Rogowsky, P. 1989. DNA transfer from Agrobacterium to Zea mays or Brassica by agroinfection is dependent on bacterial virulence functions. Mol. Gen. Genet. 217:309-316.

15. Guerin, J., Rossel, J. B., Robert, S., Tsuchiya, T., and Koltunow, A. 2000. A DEFICIENS homologue is down-regulated during apomictic initiation in ovules of Hieracium. Planta 210:914-920.

16. Hanley-Bowdoin, L., Settlage, S. B., Orozco, B. M., Nagar, S., and Robertson, D. 1999. Geminiviruses: Models for plant DNA replication, transcription, and cell cycle regulation. Crit. Rev. Plant Sci. 18:71-106.
17. Hanley-Bowdoin, L., Settlage, S. B., and Robertson, D. 2004. Reprogramming plant gene expression: A prerequisite to geminivirus DNA replication. Mol. Plant Pathol. 5:149-156.

18. Hanson, P., Green, S. K., and Kuo, G. 2006. Ty-2, a gene on chromosome 11, conditioning geminivirus resistance in tomato. Rep. Tomato Genet. Coop. 56:17-18.

19. Hanson, P. M., Bernacchi, D., Green, S., Tanksley, S. D., Muniyappa, V., Padmaja, A. S., Chen, H.-M., Kuo, G., Fang, D., and Chen, J.-T. 2000. Mapping a wild tomato introgression associated with Tomato yellow leaf curl virus resistance in a cultivated tomato line. J. Am. Soc. Hortic. Sci. $125: 15-20$

20. Hehnle, S., Wege, C., and Jeske, H. 2004. Interaction of DNA with the movement proteins of geminiviruses revisited. J. Virol. 78:7698-7706.

21. Ji, Y., and Scott, J. W. 2006. Ty-3, a begomovirus resistance locus linked to $T y-1$ on chromosome 6 of tomato. Rep. Tomato Genet. Coop. 56:22-25.

22. Kalloo, D., and Banerjee, M. K. 1990. Transfer of Tomato leaf curl virus resistance from Lycopersicon hirsutum f. glabratum to L. esculentum. Plant Breed. 105:156-159.

23. Kasrawi, M. A., Suwwan, M. A., and Mansour, A. 1988. Sources of resistance to Tomato yellow leaf curl virus (TYLCV) in Lycopersicon species. Euphytica 37:61-64.

24. Kheyr-Pour, A., Bendahmane, M., Matzeit, V., Accotto, G. P., Crespi, S., and Gronenborn, B. 1991. Tomato yellow leaf curl virus from Sardinia is a whitefly-transmitted monopartite geminivirus. Nucleic Acids Res. 19:6763-6769

25. Kheyr-Pour, A., Gronenborn, B., and Czosnek, H. 1994. Agroinoculation of Tomato yellow leaf curl virus (TYLCV) overcomes the virus resistance of wild Lycopersicon species. Plant Breed. 112:228-233.

26. Lapidot, M., and Friedmann, M. 2002. Breeding for resistance to whitefly-transmitted geminiviruses. Ann. Appl. Biol. 140:109-127.

27. Lapidot, M., Friedmann, M., Lachman, O., Yehezkel, A., Nahon, S., Cohen, S., and Pilowsky, M. 1997. Comparison of resistance level to Tomato yellow leaf curl virus among commercial cultivars and breeding lines. Plant Dis. 81:1425-1428.

28. Lee, S., Stenger, D. C., Bisaro, D. M., and Davis, K. R. 1994. Identification of loci in Arabidopsis that confer resistance to geminivirus infection. Plant J. 6:525-535.

29. McGarry, R. C., Barron, Y. D., Carvalho, M. F., Hill, J. E., Gold, D., Cheung, E., Kraus, W. L., and Lazarowitz, S. G. 2003. A novel Arabidopsis acetyltransferase interacts with the geminivirus movement protein NSP. Plant Cell 15:1605-1618.

30. Michelson, I., Zamir, D., and Czosnek, H. 1994. Accumulation and translocation of Tomato yellow leaf curl virus (TYLCV) in a Lycopersicon esculentum breeding line containing the L. chilense TYLCV tolerance gene $T y-1$. Phytopathology 84:928-933.

31. Moffat, A. S. 1999. Geminiviruses emerge as serious crop threat. Science 286:1835.

32. Moriones, E., and Navas-Castillo, J. 2000. Tomato yellow leaf curl virus, an emerging virus complex causing epidemics worldwide. Virus Res. 71:123-134.

33. Navot, N., Pichersky, E., Zeidan, M., Zamir, D., and Czosnek, H. 1991. Tomato yellow leaf curl virus: a whitefly-transmitted geminivirus with a single genomic component. Virology 185:151-161.

34. Nicaise, V., German-Retana, S., Sanjuan, R., Dubrana, M. P., Mazier, M., Maisonneuve, B., Candresse, T., Caranta, C., and LeGall, O. 2003. The eukaryotic translation initiation factor $4 \mathrm{E}$ controls lettuce susceptibility to the potyvirus Lettuce mosaic virus. Plant Physiol. 132:1272-1282.

35. Padidam, M., Beachy, R. N., and Fauquet, C. M. 1995. Tomato leaf curl geminivirus from India has a bipartite genome and coat protein is not essential for infectivity. J. Gen. Virol. 76:25-35.

36. Pico, B., Diez, M. J., and Nuez, F. 1996. Viral diseases causing the greatest economic losses to the tomato crop. 2. The Tomato yellow leaf curl virus-A review. Sci. Hortic. 67:151-196.

37. Pico, B., Ferriol, M., Diez, M. J., and Nuez, F. 1999. Developing tomato breeding lines resistant to Tomato yellow leaf curl virus. Plant Breed. 118:537-542.

38. Pilowsky, M., and Cohen, S. 1990. Tolerance to Tomato yellow leaf curl virus derived from Lycopersicon peruvianum. Plant Dis. 74:248-250.

39. Pilowsky, M., and Cohen, S. 2000. Screening additional wild tomatoes for resistance to the whitefly-borne Tomato yellow leaf curl virus. Acta Physiol. Plant. 22:351-353.

40. Polston, J. E., McGovern, R. J., and Brown, L. G. 1999. Introduction of Tomato yellow leaf curl virus in Florida and implications for the spread of this and other geminiviruses of tomato. Plant Dis. 83:984-988.

41. Qin, S., Ward, B. M., and Lazarowitz, S. G. 1998. The bipartite geminivirus coat protein aids BR1 function in viral movement by affecting the accumulation of viral single-stranded DNA. J. Virol. 72:9247-9256.

42. Rasheed, M. S., Selth, L. A., Koltunow, A. M., Randles, J. W., and Rezaian, M. A. 2006. Single-stranded DNA of Tomato leaf curl virus accumulates in the cytoplasm of phloem cells. Virology 348:120-32. 
43. Rigden, J. E., Dry, I. B., Krake, L. R., and Rezaian, M. A. 1996. Plant virus DNA replication processes in Agrobacterium: Insight into the origins of geminiviruses? Proc. Natl. Acad. Sci. USA 93:10280-10284.

44. Rom, M., Antignus, Y., Gidoni, D., Pilowsky, M., and Cohen, S. 1993. Accumulation of Tomato yellow leaf curl virus DNA in tolerant and susceptible tomato lines. Plant Dis. 77:253-257.

45. Ruffel, S., Dussault, M. H., Palloix, A., Moury, B., Bendahmane, A., Robaglia, C., and Caranta, C. 2002. A natural recessive resistance gene against Potato virus $Y$ in pepper corresponds to the eukaryotic initiation factor 4E (eIF4E). Plant J. 32:1067-75.

46. Selth, L. A., Dogra, S. C., Rasheed, M. S., Healy, H., Randles, J. W., and Rezaian, M. A. 2005. A NAC domain protein interacts with Tomato leaf curl virus replication accessory protein and enhances viral replication. Plant Cell 17:311-325.

47. Selth, L. A., Dogra, S. C., Rasheed, M. S., Randles, J. W., and Rezaian, M. A. 2006. Identification and characterization of a host reversibly glycosylated peptide that interacts with the Tomato leaf curl virus V1 protein. Plant Mol. Biol. 61:297-310.

48. Stonor, J., Hart, P., Gunther, M., DeBarro, P., and Rezaian, M. A. 2003. Tomato leaf curl geminivirus in Australia: Occurrence, detection, sequence diversity and host range. Plant Pathol. 52:379-388.

49. Thomas, M. R., Matsumoto, S., Cain, P., and Scott, N. S. 1993. Repetitive DNA of grapevine: Classes present and sequences suitable for cultivar identification. Theor. Appl. Genet. 86:173-180.

50. van Regenmortel, M. H. V., Mayo, M. A., Fauquet, C. M., and Maniloff, J. 2000. Virus nomenclature: Consensus versus chaos. Arch. Virol. 145: 2227-2232.
51. Varma, A., and Malathi, V. G. 2003. Emerging geminivirus problems: A serious threat to crop production. Ann. Appl. Biol. 142:145-164.

52. Vidavsky, F., and Czosnek, H. 1998. Tomato breeding lines resistant and tolerant to Tomato yellow leaf curl virus issued from Lycopersicon hirsutum. Phytopathology 88:910-914.

53. Vidavsky, F., Leviatov, S., Milo, J., Rabinowitch, H. D., Kedar, N., and Czosnek, H. 1998. Response of tolerant breeding lines of tomato, Lycopersicon esculentum, originating from three different sources $(L$. peruvianum, L. pimpinellifolium and L. chilense) to early controlled inoculation by Tomato yellow leaf curl virus (TYLCV). Plant Breed. 117:165-169.

54. Voinnet, O. 2001. RNA silencing as plant immune system against viruses. Trends Genet. 17:449-459.

55. Waterhouse, P. M., Wang, M. B., and Lough, T. 2001. Gene silencing as an adaptive defence against viruses. Nature 411:834-842.

56. Williams, J. G. K., Kubelik, A. R., Livak, K. J., Rafalski, J. A., and Tingey, S. V. 1990. DNA polymorphisms amplified by arbitrary primers are useful as genetic markers. Nucleic Acids Res. 18:6531-6535.

57. Zakay, Y., Navot, N., Zeidan, M., Kedar, N., Rabinowitch, H., Czosnek, H., and Zamir, D. 1991. Screening Lycopersicon accessions for resistance to Tomato yellow leaf curl virus-Presence of viral DNA and symptom development. Plant Dis. 75:279-281.

58. Zamir, D., Ekstein-Michelson, I., Zakay, Y., Navot, N., Zeidan, M., Sarfatti, M., Eshed, Y., Harel, E., Pleban, T., Vanoss, H., Kedar, N., Rabinowitch, H. D., and Czosnek, H. 1994. Mapping and introgression of a Tomato yellow leaf curl virus tolerance gene, Ty-1. Theor. Appl. Genet. 88:141-146. 